\title{
X-chromosome gene dosage as a determinant of impaired pre and postnatal growth and adult height in Turner syndrome
}

\author{
Elodie Fiot', Delphine Zenaty', Priscilla Boizeau ${ }^{4,5}$, Jeremy Haigneré4,5, \\ Sophie Dos Santos ${ }^{1}$, Juliane Léger ${ }^{1,2,3}$ on behalf of The French Turner Syndrome \\ Study Group* \\ ${ }^{1}$ Assistance Publique-Hôpitaux de Paris, Hôpital Robert Debré, Service d'Endocrinologie Diabétologie Pédiatrique, \\ Centre de Référence des Maladies Endocriniennes Rares de la Croissance, INSERM U 1141, 48 Bd Sérurier, F-75019 \\ Paris, France, ${ }^{2}$ Université Paris Diderot, Sorbonne Paris Cité, F-75019 Paris, France, ${ }^{3}$ Institut National de la Santé \\ et de la Recherche Médicale (Inserm), Unité 1141, DHU Protect, F-75019 Paris, France, ${ }^{4}$ AP-HP, Hôpital Robert \\ Debré, Unit of Clinical Epidemiology, F-75019, Paris, France, and 5 Inserm, CIC-EC 1426, F-75019 Paris, France \\ *(Details of the French Turner Syndrome Study Group is presented in the Acknowledgements section)
}

Correspondence should be addressed to J Léger Email

juliane.leger@aphp.fr

The authors apologise for errors in the names of three participants of the French Turner Syndrome Study Group that were listed in the Acknowledgements section of the this article published in the March 2016 isse (Vol 174 pp 281-288). S Christin Maître, D Samara Boustani and M Pepin Donat should read as S Christin-Maître, D Samara-Boustani and M Pepin-Donat. The corrected list of the participants as given in the Acknowledgements section is published in full below:

\section{Acknowledgements}

The following participated in the French Turner Syndrome Study Group (French National Rare Disease Network): J C Carel, S Cabrol, P Chanson, S Christin-Maître, C Courtillot, B Donadille, J Dulon, M Houang, M Nedelcu, I Netchine, M Polak, S Salenave, D Samara-Boustani, D Simon, P Touraine, M Viaud (Paris); H Bony, K Braun, R Desailloud (Amiens); A M Bertrand, B Mignot, F Schillo (Besançon); P Barat (Bordeaux); V Kerlan, C Metz, E Sonnet (Brest); Y Reznik, V Ribault, (Caen); H Carla, I Tauveron (Clermont Ferrand); C Bensignor, F Huet, B Verges (Dijon); O Chabre, C Dupuis, A Spiteri (Grenoble); M Cartigny, C Stuckens, J Weill (Lille); A Lienhardt (Limoges); C Naud Saudreau (Lorient); F Borson-Chazot, A Brac de la Perriere, M Pugeat (Lyon); T Brue, R Reynaud, G Simonin (Marseille); F Paris, C Sultan (Montpellier); B Leheup, G Weryha (Nancy); S Baron, B Charbonnel, S Dubourdieu (Nantes); E Baechler, P Fenichel, K Wagner (Nice); F Compain (Poitiers); H Crosnier, C Personnier (Poissy); B Delemer, A C Hecart, P F Souchon (Reims); M De Kerdanet, F Galland, S Nivot-Adamiak (Rennes); M Castanet, C Lecointre, (Rouen); O Richard (Saint Etienne); N Jeandidier, S Soskin (Strasbourg); and P Lecomte, M Pepin-Donat, P Pierre (Tours).

() 2016 European Society of Endocrinology Printed in Great Britain
Published by Bioscientifica Ltd. 